\title{
Internationalization of Albanian Firms: Challenges and Opportunities
}

\author{
Assoc.Prof. Dr. Marsida Ashiku \\ Head of Finance-Accounting Department; University "Aleksandër Xhuvani", Elbasan; ALBANIA
}

\begin{abstract}
In this paper we examine how the level of internationalization, i.e. a firm's relative exposure to foreign sales, affects individual SMEs in Albania. Since it is conducted using a data sample with albanian SMEs, its applicability in other countries may vary. The purpose of this study is to increase the knowledge and provide insights on how internationalization affects SMEs in general and in Albania in particular. This empirical analysis aims to study if Albanian firms are internationalized or not, for a panel of 50 Albanian small and medium enterprises for the period 2014 to 2015 . For the realization of this paper we were based on a rich contemporary literature but also in the analysis of data obtained from firms' balances and from a survey in Albanian firms for the last 2 years. Results of this work will help the work of managers and financial managers in Albanian companies, but also other persons interested in the field of international finance, at a time when the main reason for the financial crisis in the world nowdays is precisely the lack of liquidity which consequently leads to the reduction of exports to foreign international markets.
\end{abstract}

Keywords: internationalization, small and medium enterprises (SME), sales, Albania.

JEL classification: F3, F10, F20.

\section{INTRODUCTION}

From a historical perspective, the internationalization of businesses and firms with the ability of humanity began to travel across the seas and beyond borders. Anyway internationalization is essentially a version of the interaction between attitudes and actual behavior; empirical studies have focused on the observation of aspects of internationalization which are international ${ }^{1}$. Certain research activities explain the "internationalization" as external movement of international operations of a firm (Johanson \& Wiedersheim, 1975). This common feature is enhanced by considering more "internationalization" as "an orderly and sequential process of increasing international involvement and associated changes in the organization of a firm. ${ }^{2}$ Increased trade in various forms of clean exchanges to make arrangements, connecting external growth performance of internal part which is shown more in the growth of international engagement through the ability of many companies to connect with international suppliers. Given the increased cooperation from within - outside, Welch \& Luostarinen (1988) suggest a broader definition including both sides of the process, defining internationalization "as the process of increasing involvement in international operations".

Internationalization is an important issue in today's business environment, which varies constantly. It has become a constant for business organizations, which need to change in order to remain competitive in market. Internationalization is widespread in last decades, and the process of internationalization of a firm has attracted many academics. This process was initially originated from Johanson and Wiedersheim - Paul (1975) and Johanson and Vahlne (1977), and is reviving after the (Eriksson, Johanson, Majkgard and Sharma, 2000). Is hard to imagine functioning of an economy isolated from others, from the international market of goods, services and factors of the international produce. The importance takes a load even greater in terms economies in transition, due to isolation deep in the past. Foreign trade is among the most vital

\footnotetext{
1 Johanson \& Wiedersheim, 1975.

2 Reid, 1981; Bilkey \& Tesar, 1977; Johanson \& Vahlne, 1977.
} 
sectors of economic development of a country and is an inexhaustible wealth, as a source of income both locally, nationally and internationally.

Like other countries of Western Balkans, which are well on their way towards European Integration, internationalization remains a challenge for Albania. Most of these countries underwent liberalization and privatization process on a large scale, adding expanding sector of small and medium enterprises (SME). It is widely accepted that the SME sector can play a key role in the process of internationalization. It is well articulated in theory and practice that the contribution of SMEs to a new job, exports, innovation and regional development is vital to a country's national development. Also, small and medium firms could be an important factor to promote competition and market efficiency tool. If your reading of the events in Albania on issues of internationalization, which comes first, the state is relatively weak, and secondly, not only that but is somehow unable to enter the competition in the global market. However Albania even in this position is, is undergoing phenomena of globalization, internationalization and consequently, the best and the worst of it.

The object of this study, are a finite number of Albanian enterprises and small medium enterprises that operate in several different branches of industry, in several key districts of Albania, mainly in the districts of Elbasan as: Durres, Tirana, Kavaja, Fier; to see if they are internationalized and in how their foreign sales will affect their performance. This paper has its values in theory and practice as well microeconomic and macroeconomic context, but at the same time restrictions. Size selection of businesses in the study is small (50) as a result of the limited time and opportunities for obtaining data from diferent firms. As a result, care should be taken in attempting to generalize the findings of this study. This paper is focused only on small and medium firms since they constitute an important part of economic development and dynamic not only for advanced countries of the industrialized, but also for developing economies like Albania. Results of this work will help the work of managers and financial managers in Albanian companies, but also other persons interested in the field of international finance, at a time when the main reason for the financial crisis in the world today is precisely the lack of liquidity which consequently leads to the reduction of exports to foreign international markets.

\section{DATA AND METHODOLOGY}

For the conception and development of this empirical work, after a preliminary selection was used a variety of information sources such as studies of domestic and foreign authors in this field as well as on a wide number of sources of information from official websites of relevant institutions, as with national and international character. Also for the realization of this empirical paper, we are supported in local literature, but in the case of our country, unlike world literature, are carried very little. Based on the techniques recommended by the literature on research methodology was conducted a questionnaire about internationalization Albanian firms, mainly in central Albania. Realization of a questionnaire about internationalization , was the best way to gather information directly from its administrators \ owners of the firm. The data collected and processed from the questionnaire used to prove the hypothesis about the lack of knowledge and awareness of firms and Albanian businessmen in their internationalization, unlike foreign firms. Information is collected in a panel of 50 firms for the last 2 years (2012-2013). The primary data collected through the survey are processed through the program SSPS 17.

\section{LITERATURE REVIEW}

\subsection{Internationalization through exporting}

Many in the international trade literature shows that export activity is the greatest activity in the business world. Traditionaly, internationalization through export is considered one of the best ways to increase firms. Export is still important, but in recent decades, firms have been focused in various activities for the process of internationalization and exports have deemed important enough to create competitive advantages. Partnerships with foreign companies, foreign investment and international networks have become increasingly important to facilitate the exchange of technology and knowledge and enable SMEs to formulate solid business strategy. Globalism, technology, political and economic changes are the main factors for the growth of internationalization of SMEs nowadays.

Exporting is the most popular and fast way for small and medium enterprises to become international. The level of risk and liability is reduced when investments managerial and financial resources is not considered compared with other modes of enter of goods. Because different from foreign markets requires less commitment to organizational assets offering higher flexibility of managerial actions and commits less business risk. For some firms this is a very successful way for their 
internationalization. Some times exporting is viewed as the first step on the road to a deep commitment to internationalization. Some firms, however, try to enter in foreign markets through exports but they fail. But failure in international markets can be costly in terms of financial resources and management and given opportunities. For these reasons, exporting as an entry strategy wich should be followed carefully.

International expansion through wholly owned subsidiaries takes place within the MNE when the benefits of internalization (in terms of developing, deploying, exploiting and augmenting FSAs) outweigh both the costs of doing business abroad at both national and regional levels, and the resulting net benefits are higher than those associated with alternative entry modes (exporting, licensing, or joint ventures). Previous research on this topic have shown different results depending on the country to investigate and the natyre of the study. In contrast, Burgman (1996) presents the results of his study which show that internationalization increases costs and reduces the transparency of the agency, causing a higher risk loan. Arslan and Karan conduct a similar study in Turkey in 2009, but the Turkish market was substantially different from other markets. The authors concluded that different variables affected the credit risk depending on the level of internationalization of the firm. While Rugman study (1981) shows that an SME should be based on theories of internationalization because they provide clear conditions for selecting the entry ways in international markets.

\subsection{MOTIVES AND FACTORS AFFECTING THE PROCESS OF INTERNALIZATION}

\subsubsection{MOTIVES}

There are several different reasons for the internationalization of SMEs indicating a diversified approach to internationalization. One of the most common reasons is to gain access to new markets and larger to achieve a greater economic growth. Firms expand their market for exporting products or creating subsidiaries or joint ventures established abroad. Many firms go abroad to have a wider access to knowledge and technology in order to remain competitive in market .the purpose of internationalization of a firm is influenced by foreign market opportunities. These opportunities are incentives only if the company has sufficient resources necessary to enter this market. There are two reasons to analyze why SMEs decide to became international. Firms can receive incentives of internal or external in deciding to start the export, both internal qualities and environmental factors play an important role.

\subsubsection{FACTORS}

Motivating factors. Export motivating factors are defined as "all those factors that affect a firm's decision to initiate, develop or support export operations"; and the factors that prevent it are "all those behavioral factors, structural, operational, and other restrictions that impede the ability of the firm to start, develop or support international operations. motivating factors explain why some firms involved and continue exporting . Wiedersheim-Paul, et al. (1978) classifies as motivating factors: internal factors and external. Internal factors have their origins in the firm's concentration in unique products or unused resource capacity. On the other hand factors outside are associated with the external environment of firms (domestic or foreign environment), as exports related government incentives or foreign market opportunities. Often external motivating factors considered as reactive and proactive as internal ones.

Hindering factors. While hindering factors explain why some firms engaged in export not use their full potential in the path of internationalization. Different terms are used in literature refers to these factors including: incentives, and incentives for motivating factors, problems, barriers and restrictions hindering factors. Piercy (1981) classifies the motivational factors: reactive and proactive factors.

Reactive factors. Reactive factors explain the behavior of exporting firms as a response to changing conditions reflecting the passive behavior of firms looking for export opportunities. We also show how a firm reasons can act passively and respond to pressure as internal and external: the competition. Another factor that makes firms to operate in passive mode is when a firm is specialized in the marketing of it, after possesing specific knowledge will make them different to competitors. But marketing advantage can then serve as a barrier to foreign competition (Albaum, Strandskov \& DUERR, 1998).

Proactive factors. On the other hand proactive factors are associated with unique powers or interests firms, taking advantage of market opportunities as well as competitive advantages or possession of information on foreign markets, showing aggressive behavior in search of export opportunities. Proactive factors indicate that the selection of a firm to 
internationalize affected by internal means: interest to exploit ideas and unique skills, as well as the opportunities offered by foreign markets. The management team has the desire, motivation, enthusiasm and commitment to the market. Knowing the local and international market, and utilizing the competitive advantage that a firm has over another company; as quickly as possible, the host country and his management team will be able to act proactively and begin to plan a strategy to internationalize.

\subsubsection{THEORIES OF INTERNATIONALIZATION}

Going back through history we find many theories that talk about the process of internationalization of firms in different ways. But not all theories are applicable to any case of internationalization that happens in the business world, but they often complement each other and work as different tools to explain and understand the process of internationalization of firms. Some of the most important theories that influence this process are listed as follows:

\section{Uppsala model of internationalization process (U-model)}

According Mitgwe (2006), the search firm's internationalization process in the U-Model, comes from the Nordic schools. The theoretical framework for this theory was first developed by Johansson and Wiedersheim-Paul (1975) in their study of four Swedish firms, in which they noted that when firms internationalize, they move together in a growing series of steps which they called as "chain establishment" or "step by step". The theory focuses on four aspects that a firm must face going abroad: market knowledge and commitment, and current activities which are divided into various phases and aspects of interacting with one another in what seems to be a cycle. state aspects are resources used in the overseas market, market knowledge and commitment decisions that will affect the chances of the firm and its risks. Market engagement has to do with those resources that will be used and the degree of involvement. Aspects of change are the results of the aspects of the state. Once the firm has obtained knowledge about the market, they can decide the way in which they engage in this market, and therefore they will then be able to plan and execute the actual activities necessary to complete the cycle of introduction a foreign market. The basic assumption is that knowledge Uppsala model and market commitments affect both the decisions of engagement and how the actual decisions are made. Most of the knowledge and operations of foreign markets affected by the amount of exploitation of resources in these markets, and vice versa. Continued growth also suggests that companies begin the process of internationalization in markets that have less physical distance.

\section{Network Theory}

Uppsala model has changed a lot recently by Network Theory where basic argument is that firms with a high and modern technology are not exposed to the process of growth, only if they do not follow a rapid internationalization process through experience and resources with partners which they will relate. All firms in a market seems to be involved in many networks through connections of bidders, subcontractors and other market factors. According to Emerson (1981), a network composed of two or more business connections, in which each exchange takes place between business firms which are conceived as joint actors in a market. Network Theory theorists see an internationalized firm as a natural development through network connections with individuals and foreign firms. Network communication viewed as a informational resource for the market and his knowledge, which often required long-term terms when they have no connection with the host country. However, the networks create a basic mechanism that affects a rapid internationalization of a firm and better communication with offers, or with other companies.

\section{International Entrepreneurship Theory (EIT)}

According to Zahra and George (2002), the term "International Entrepreneurship" is originally appeared in a short article by Morrow in 1988. Morrow suggests that developments in technology, removing cultural barriers and increasing cultural awareness have opened the foreign market to All kinds of companies; small firms, new enterprises as well as big companies. Years later, McDougall's empirical study (1989) by comparing new domestic enterprises and international ones, opened the way for academic studies in international entrepreneurship. International Entrepreneurship is the study "crossborder" entrepreneurial behavior that focuses on what market players discover, approve, analyze and exploit the opportunities in the creation of goods and services. McDougall and Oviatt's (2000, p. 903) determine their definition of international entrepreneurship as "a combination of innovation, and to risk behavior that crosses international boundaries and that aims to create value for the organization." International Entrepreneurship Theory implies that the behavior of 
individuals and entrepreneurial firms is the basis for entering a foreign market. Technological developments, roads free and easy to access to information and better communication between the two countries have helped SMEs -to go to foreign markets. Nowadays they are being internationalise quickly, with the exception of newly created enterprises.

\section{ANALYSIS AND RESULTS}

\section{Internationalization of Albanian firms}

Albanian literature studies are primarily associated only with a particular business, such as banks or financial intermediaries, and never for trading firms, manufacturing or different types. Precisely for this reason, our study is focused on these firms to see how they act towards foreign sales that they realize, credit risk, as they devote appropriate importance of the internationalization process in such a time of global financial crisis . Based on the data collected for the first application of theoretical concepts in practice Albanian firms regarding internationalization and the main motives why Albanian firms go towards internationalization, Chart 4.1 present statistical results about the knowledge and theories that explain its operation

\section{Chart 4.1: Do you know about internationalization and his theories?}

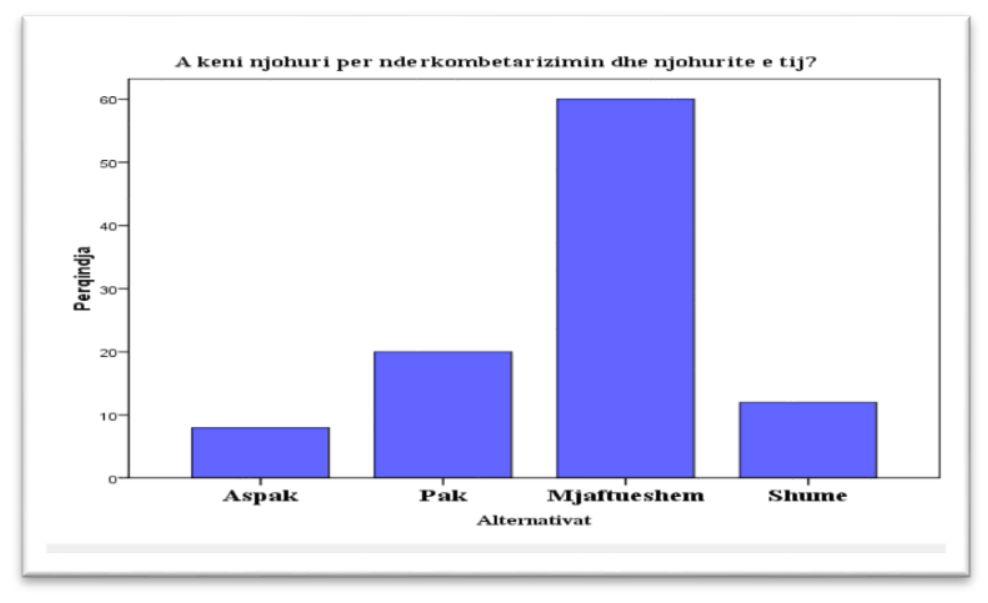

Albanian firms, as seen above do not have numerous knowledge (100\%) for the process of internationalization. Only 30 of them had sufficient knowledge about this process but were not familiar with the appropriate terms about, which affects later in making the right decisions by their managers to operate in foreign markets.

\section{Chart 4.2: What are the main motivations for becoming involved in foreign financial markets?}




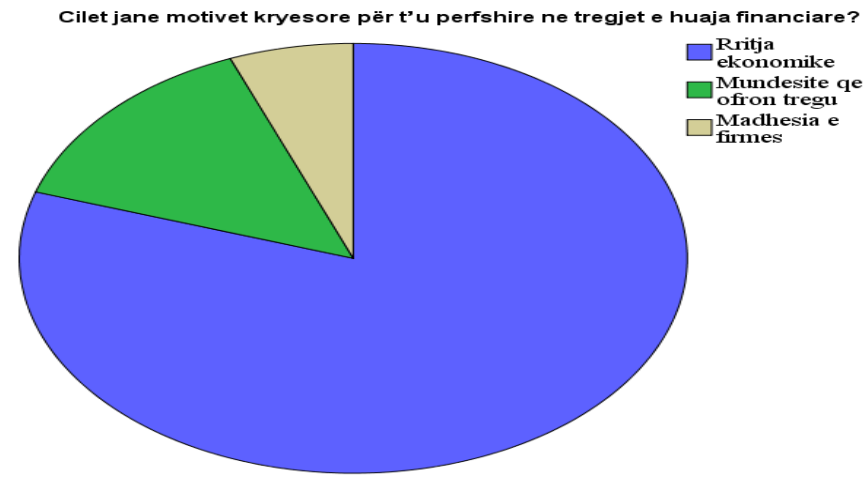

As we have discussed before, there are two factors that affect the internationalization of SMEs: proactive and reactive factors; they give reasons SMEs to internationalize. Chart 4.2 suggests that the majority of SMEs surveyed, move towards international markets due to market opportunities, economic growth and to increase the size of the firm.

$80 \%$ of surveyed firms go towards internationalization to take advantage of economic growth, $14 \%$ for the opportunities that the market offers them and only a small percentage of them, or $6 \%$, due to increasing the size of their firm.

\section{Chart 4.3: What do you think about the profitability of firms as a result of internationalization?}

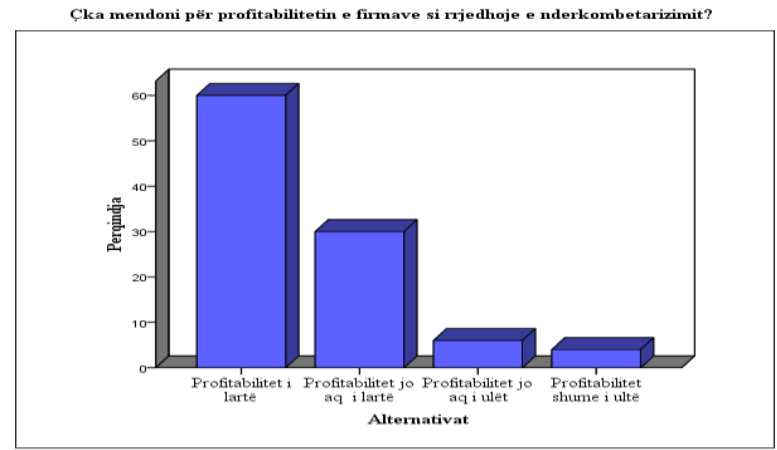

We would like to see the findings of the questionnaire regarding the profitability of firms as a result of internationalization. Even browsing the literature noted that internationalization increases the profitability of a firm. In our case it is observed that $60 \%$ of firms think that internationalization brings a high profitability (30\% a not so high profitability and $6 \%$ a not so low profitability), and only very few of them, $4 \%$ think that internationalization brings them a very low profitability for their firm.

Very valuable are the results that are obtained from the following questions about the speed of the process to realize the internationalization of Albanian firms and how this affects the physical distance process. By seing chart 4.4, we note that $80 \%$ of surveyed thought the internationalization of their firms is slow and consequently the difficult financial situation they are experiencing in terms of a global economic crisis and only $2 \%$ of them are characterized by a rapid internationalization process. While $8 \%$ of them are involved not too fast in this process.

\section{Chart 4.4: How fast is the process of internationalization?}




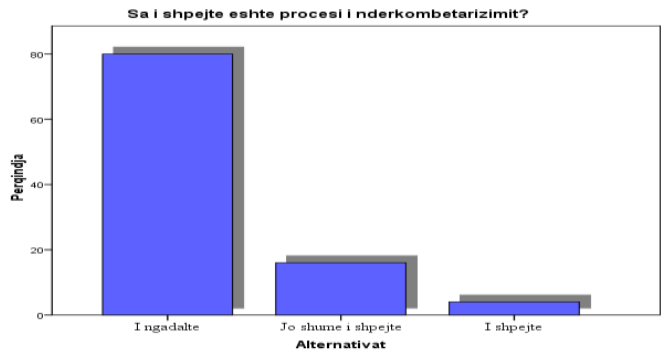

This once again shows that the process of internationalization of INV's is hard to explain the U-pattern; since most SMEs that we are discussing here are not very old enterprises (since their creation and until 2013) and Albanian firms seem to have a slow process, as it suggests and $U$ model.

\section{Chart 4.5: How much does the distance affect in internationalization?}

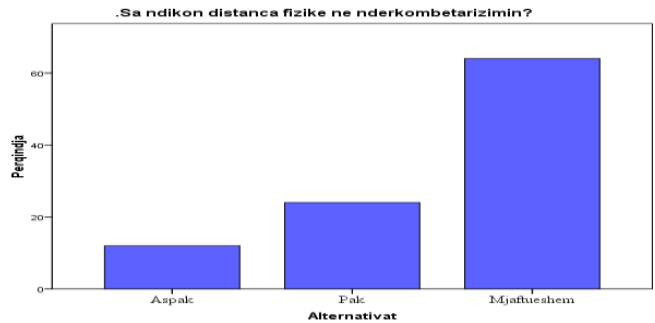

As we have seen above, the physical distance is an important factor for these firms. It is noted that $64 \%$ of firms believe that physical distance affects many in their internationalization process. Therefore, they try to aim countries with lower physical distance market and businesses with similar culture (Chart 4.5). Areas that are needed to create this kind of business; in a sense reasons are related to the physical distance indirectly, rather than directly. Thus, these findings may very well look at Uppsala model.

\section{Chart 4.6: How important is the position of the internal market in the process of internationalization?}

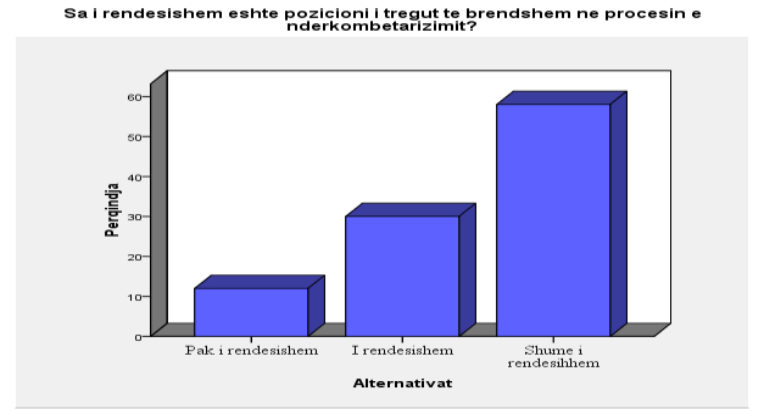

From new chart shows that Albanian firms (about 58\%) of the estimate very important domestic market position in the process of internationalization. Even if further analysis, SMEs appear to be less concerned about their position in the 
domestic market. Some firms even considered to be a small firm in the market, do not consider their position in the domestic market which is in the "surge"; to be important in all aspects of internationalization. But most of the SMEs with a strong and leading position in the domestic markets consider it as beneficial to their internationalization.

\section{Chart 4.7: Does your company's internationalization effect in the following areas?}

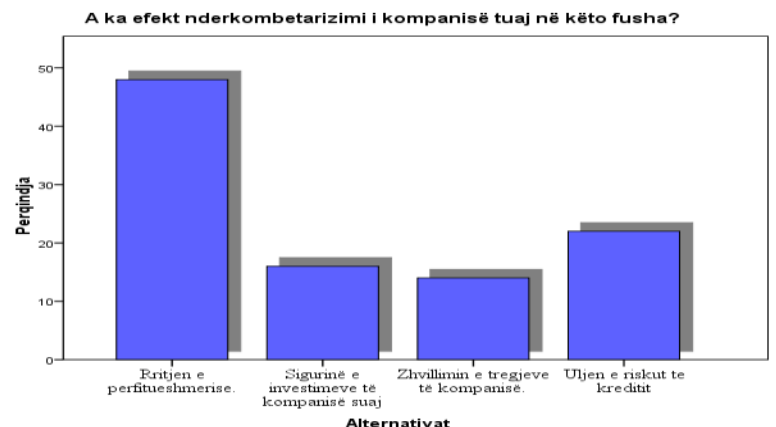

Graphically seen very clearly that internationalization effects on Albanian firms. Specifically $48 \%$ of firms think that internationalization has an important role in increasing the profitability of the firm, $16 \%$ of them think that internationalization affects the security of their investment company, also $12 \%$ think that internationalization brings the company's developing markets, and $24 \%$ think that internationalization brings reducing credit risk for their firm.

Some of the reasons that companies see as the most important, and that prevent them from realizing exports in foreign markets are: tariff barriers, lack of information on foreign markets but also high transport costs, respectively in these percentages $26 \%, 18 \%$ and $12 \%$.

\section{Chart 4.8: What are the main obstacles to export?}

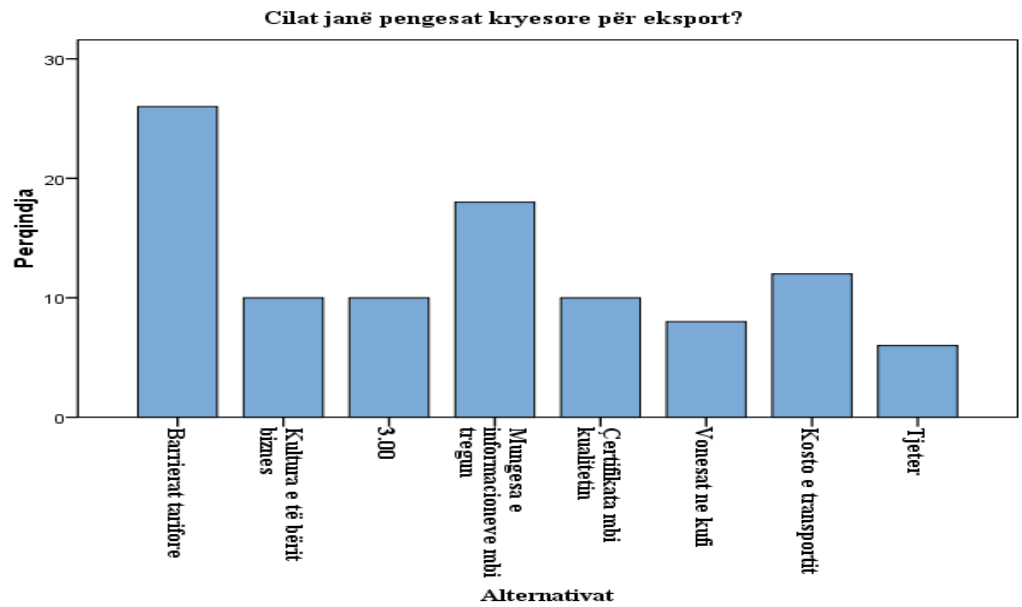

\section{Chart 4.9: The most important markets that export?}




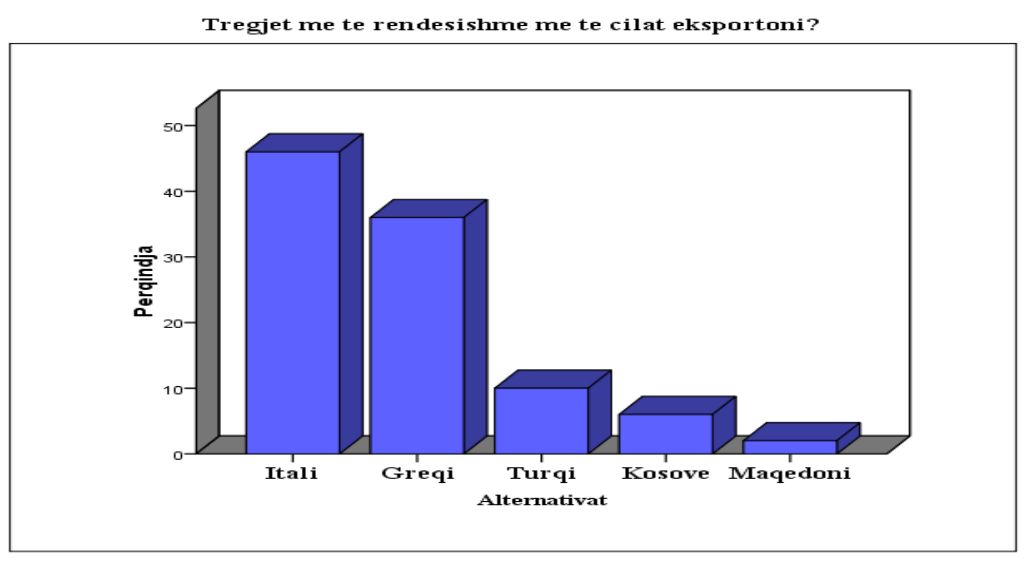

As you can see above the studied firms have focused their exports in countries such as Italy and Greece, so 23 of them with Italy and 18 in Greece and the rest of Turkey, Kosovo and Macedonia. As a result of the financial crisis it is observed that the level of exports in monetary value has fallen in recent years mainly by these two countries.

\section{Chart 10.4: Do they get a loan from the bank?}

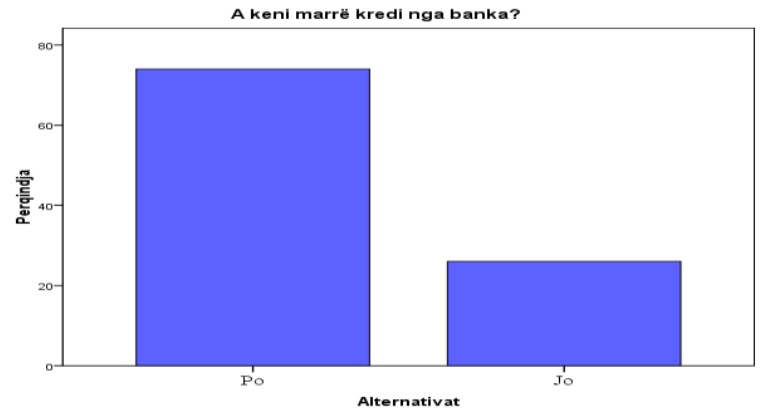

It is noted that $74 \%$ of firms included in the study have applied for credit and been granted, then we say that they use it as a tool to settle numerous obligations that may have but also different ways of financing for the company. While $26 \%$ stated that they have not applied any time for obtaining a loan.

Chart 4.11: Does the manager previous experience affect to your firm in international business? 


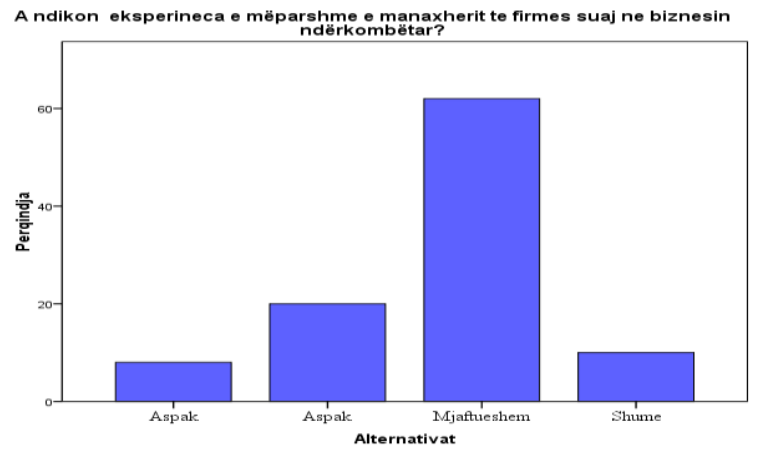

Having prior knowledge about international business, helps SMEs in the process of internationalization. As chart 11.4 shows, 30 of the SMEs, or $60 \%$ of them sees as an important factor having a manager or the owner or founder with such experiences in international business, while others respectively $20 \%, 16 \%$ and $4 \%$. Previous management experience in international business will significantly help them to speed the process, but the leaders of the Albanian firms do not pay attention to the development of knowledge about this area, but prefer to run their activities more within the country.

\section{CONCLUSIONS AND RECOMMENDATIONS}

Despite that in Western countries there is a vast literature on internationalization and a series of studies on the various factors that influence its results, in our country this field of study is still new and uncharted. Therefore, the purpose of our paper was to analyze whether firms (businesses) Albanian or not internationalized. The most important economic benefit of internationalization is low cost and global growth in business and commerce. Looking at international markets and global customers to purchase products and creating global demand for local products, leading to increased internationalization of the activities of a business. In business performance internationalization provides a positive connection between commitment to an SME in international and high rates of turnover growth but higher growth rates of employment seizures inactive SMEs in their international activities.

Also, after analyzing the survey data, we find out that the internationalization of Albanian firms is a slow process. Managers or executives directors of Albanian firms see internationalization as a high-cost process for them, so they do not pay attention as the proper process, but also about his knowledge development, which will be magnified as helps them a lot in their profitability and a lower probability of failure. Executive Manager initially supports internationalization and should see it as "a desirable task for the firm" then deals with the preservation of its image and securing investment. The fact that they are less internationalized increases their chances of failure or bankruptcy.

Application of stimulus measures for exports by the government, as the simplification of bureaucratic procedures, reduction of customs duties, organization of information campaigns managers of businesses to regional and international markets, the government signed agreements on the free movement of goods with regional countries and the EU, improving road and rail infrastructure, incentives to increase the quality of local products will affect many in the internationalization process magnified as Albanian firms. Also recommended the strengthening of economic relations with other countries in the region, in order to create favorable conditions for the penetration of local products in regional markets and those of the European Union but also the creation of mitigation measures for foreign investors, including the simplification of administrative procedures; licensing of international companies which expressed interest to invest in our country.

Finally, there are many possibilities for further research in SMEs internationalization. Future study may consider investigating the relationship between SMEs demographic characteristics and the internationalization process. There could be some common factors that indicate why SMEs internationalized either in stage, through network or from its inception. Future study may also look at the internationalization process of SMEs in different industries, especially the service sector (including ICT and Primary Agriculture). Moreover, it would be a good idea to investigate the influences of government policy, culture and many other factors as a mediator or moderator variable during internationalization process. 


\section{REFERENCES}

[1] Ahokangas, P., 1998. Internationalization and resources: an analysis of proçess in Nordic SMEs, Vaasa: Universitas Wasaensis.

[2] Altman, E., 1968. Financial ratios, discriminant analysis and the prediction of corporate bankruptcy. Journal of Finance, Volume September.

[3] Altman, E. I., 2000. Predicting financial distress of companies: Revisiting the Z-score and Zeta models, New York: Stern School of Business.

[4] Altman, E. I. \& Sabato, G., 2007. Modelling Credit Risk for SMEs: Evidence from the US Market. Abacus, 43(3), pp. 332-357.

[5] Ang, J., 1992. On the theory of finance for privately held firms. Journal of Small Business Finance, 1(3), pp. 185203.

[6] Burgman, T. A., 1996. An Empirical Examination of Multinational Corporate Capital Structure. Journal of International Business Studies, 27(3), pp. 553-570.

[7] Caves, R. E., 2007. Multinational Enterprise and Economic Analysis. 3rd ed. Cambridge: Cambridge University Press.

[8] Drini Salko, Financa Nderkombetare, 2009.

[9] Jensen, C. M. \& Meckling, W. H., 1976. Theory of the firm: Mangerial behavior, agency costs and ownership structure. Journal of Financial Economics, 3(4), pp. 305-360.

[10] Johanson, J. \& Vahlne, J.-E., 1990. The Mechanism of Internationalization, 11-24: International Marketing Review.

[11] Lehtinen, U. \& Penttinen, H., 1999. Definition of the internationalization of the firm. Perspectives on Internationalization, pp. 67-82.

[12] Raporti vjetor i Bankes se Shqiperise, 2013.

[13] Rugman, A. M., 2009. International Business. 2nd ed. Oxford: Oxford University Press.

[14] Yazdanfar, D., 2012. Agency cost theory and the financing life cycle empirical evidence from Swedish firm-level data. Int. J. Business and Globalisation, pp. 226-238. 